\title{
Use of Cloud Technologies in the Process of Professional and Linguistic Training of Law Students for the Development of Academic Performance
}

\author{
Yurii S. Shemshuchenko ${ }^{1}$, Elvira M. Gerasymova ${ }^{2}$, Zorina S. Vykhovanets ${ }^{3}$, Iurii L. Mosenkis ${ }^{4}, \&$ Oleksandr M. \\ Strokal ${ }^{4}$ \\ ${ }^{1}$ Institute of State and Law, V.M. Koretsky National Academy of Sciences of Ukraine, Kyiv, Ukraine \\ ${ }^{2}$ Department of Social Philosophy, Phyilosophy and Educational Policy, Faculty of Education and Science \\ Management, National Pedagogical Dragomanov University, Kyiv, Ukraine \\ ${ }^{3}$ Department of Foreign Languages, National Pirogov Memorial Medical University, Vinnytsya, Ukraine \\ ${ }^{4}$ Department of Ukrainian Language and Applied Linguistics, Institute of Philology, Taras Shevchenko National \\ University of Kyiv, Kyiv, Ukraine \\ Correspondence: Iurii L. Mosenkis, Taras Shevchenko National University of Kyiv, 64/13, Volodymyrska Street, \\ Kyiv, 01601, Ukraine. Email: guasileus@gmail.com
}

Received: June 10, 2020

Accepted: August 3, 2020

Online Published: August 10, 2020

doi:10.5430/ijhe.v9n7p310

URL: https://doi.org/10.5430/ijhe.v9n7p310

\begin{abstract}
The objective of this study was to find out how effective the use of cloud technologies is in the formation and development of critical thinking in future lawyers. An experimental model using cloud technologies was tested in training courses in the special (Civil Law, Fundamentals of Administrative Law) and general (English for Specific Purposes, Business English) subjects of the educational professional programme for training specialists of Specialty 081 "Law".

The method of test control and the method of component analysis were used to diagnose the level of academic performance of students selected for the pedagogical experiment in the training courses. To accomplish the research objectives, the results of the author's tests (seven control points) performed by students of both groups. IBM SPSS Statistics 25.0.0.1 software was used to analyse the quantitative data. Two-tailed P-value and Student's t test were calculated for statistical processing of experimental data.

The study showed the effectiveness of the use of cloud technologies for the formation and development of critical thinking in future lawyers. The authors conclude that the use of cloud technologies in the professional and linguistic training of lawyers also facilitates feedback, which increases students' educational motivation and allows for monitoring changes in students' personality development.
\end{abstract}

Keywords: cloud technologies, critical thinking, test control methods, method of component analysis, academic performance

\section{Introduction}

The combination of the potential of cloud technologies in learning and the development of critical thinking in students allows the most optimal solution of the contradictions between the needs of a modern society, which is undergoing dramatic changes due to the accelerated informatization of all spheres of human life, and the current practice of professional training of specialists, in particular, lawyers.

The rapid entry of humankind into the era of information technology has led to a revision of the requirements of society and the labour market for the professions, professional skills and competencies in view of the new environment (Davies, Fidler \& Gorbis, 2011). The fact that it is the cognitive and creative activity that determines the economic, scientific and technological progress of any society like never before urges the problem of the cognitive and creative development of a specialist's personality. To be successful today, a specialist must have not only a set of developed competencies, but also certain cognitive and creative abilities, which has been called "critical thinking" since the middle of the last century (Beyer, 1985; Temple, 2005). The specialist's ability to think critically is 
extremely popular in a wide range of theoretical, practical and applied fields of individual's activity (Harris \& Spiker, 2012; North, Ward, Ericsson \& Williams, 2011).

The problem of developing critical thinking in future specialists as one of the basic elements of teaching (pedagogy) almost immediately occupied a leading position in educational systems (Bloom, Engelhart, Furst, Hill \& Krathwohl, 1956). Scholars from different theoretical schools and fields have begun to actively develop this problem. Interesting research has emerged on the targeted component of general and higher education (Ritchie Bates \& Deary, 2015), models of critical thinking (Sadler, 2010), styles of thinking and perception of high school students (Kaya, 2019; Minchekar, 2017; Serin Serin, Saracaloglu \& Ceylan, 2010), the role and relationship between critical thinking skills and learning outcomes of pupils/students (Ghazivakili et al., 2014; Sharma \& Neetu, 2011).

The legislative framework for the implementation of cloud technologies in the practice of the educational institutions of Ukraine includes Order of the Ministry of Education and Science of Ukraine on conducting the experimental research work "Cloud services in education" in 2014-2017 academic years, as well as other legal papers (Ministry of Education and Science of Ukraine, 2016, 2017).

The analysis of researches and publications shows that the subject of active development of Ukrainian scholars is the study of innovative learning environments in the context of informatization of society (Korsunska, 2013), smart-technologies as innovative educational technologies in the context of modern high school (Dychkivska, 2013; Solomko, 2013), innovative approaches to the organization of education (Huong, Huy \& Ha, 2018; Isaienko \& Kushmar, 2016).

However, the problem of the use of cloud technologies for the formation and development of critical thinking in the professional training of specialists is still not well explored. The objective of our study was to identify the degree of effectiveness of the use of cloud technologies in the formation and development of critical thinking in future lawyers.

\section{Research Methodology}

The hypothesis of our study is based on the assumption that the use of cloud technologies in the process of professional and linguistic training will contribute to the formation and development of critical thinking style in future lawyers, because cloud technology allows creating such a learning environment where future professionals master and/or practice such skills as information, organizational, communicative and productive literacy (Odeh, Garcia-Perez \& Warwick, 2017; Willingham, 2019). In order to confirm the hypothesis and conduct a pedagogical experiment, two training courses were selected from the special subjects of Specialty 081 "Law" Fundamentals of Administrative Law" and Civil Law and two training courses from the general subjects (English for Specific Purposes and Business English). Since the selected courses have objective significant differences in the subject, in the sets of competences determined by educational professional programmes, in the methods of educational activities, etc., the criterion for comparison and confirmation/refutation of our hypothesis is the learning outcomes of students of the experimental and control groups in the above courses.

The methodological basis for the pedagogical experiment was the "inverted lesson" method (this is a teaching model in which the teacher provides material for self-study at home, while in-person training takes place in practice. Inverted education is characterized by the use of vodcast, podcast, and pre-vodcast) (Cheng, Huang \& Lin, 2012; Ziętek \& Roehr, 2011), the case study method with the preparation of individual and/or group reporting presentations (Siegle, 2010) and the portfolio method for monitoring and fair evaluation of student achievement (Oliynyk, 2004). Of the wide range of cloud technologies, we mainly used Moodle platform, Google Drive, Google Docs, Power Point and Google Image, Google Search and Skype. Moodle platform, open-ended and multiple-choice tests were used for online testing (Romiszowski, 2012; Smith, 2017). The comparative analysis was carried out within the existing academic groups, where professional training was carried out according to typical programmes. In the control group, professional and linguistic training were carried out according to typical methods, and in the experimental group according to the experimental method, with the use of cloud technologies (Moodle platform, Google Drive, Google Docs, Power Point and Google Image, Google Search and Skype) in the process of formation of critical thinking in future lawyers. The same tests were used to evaluate students' academic performance in both groups at the same time (at each of the seven "control points"). The conditions and criteria for evaluating the results were also applied in the same way.

\subsection{Research Design}

The study was prolonged (one year and a half), and consisted of the organizational, summative, formative and final stages. At the organizational stage, we studied and analysed the state of elaboration of the studied problem, substantiated the reasonability of using cloud technologies in the educational process with the aim of forming and 
developing critical thinking in students, developed an experimental model with the use of electronic manuals for training courses Fundamentals of Administrative Law, Civil Law, English for Specific Purposes and Business English. To diagnose the level of academic achievements of students selected for the pedagogical experiment, we used the method of test control and the component analysis method (Chernilevsky, 2010).

Methods of test control of educational achievements as a special form of testing and assessment of knowledge, skills and abilities of the subjects of the educational process. In order to implement the objectives of the study, the results of the author's tests (seven control points) were performed by students of both groups; questionnaires for students and teachers; focus group survey to determine the perception of the interviewed audience of the proposed model of learning organization. IBM SPSS Statistics 25.0.0.1 software was used to analyze quantitative data. software. Two-tailed P-value and Student's t test were calculated for statistical processing of experimental data, for which an online resource for t-test calculations of independent samples was used.

To monitor changes and evaluate the level of student achievement, it was proposed to use the seven control points tests; for this purpose, the entrance control tests (control point No. 1), four modular control works for current/intermediate control (control points No. 2, 3, 5, 6) and final tests for the above mentioned training courses (control points No. 4, 7) were modified. The work was conducted in a computer room, where students had the opportunity to take tests and pass a modular test. Assessment of students' educational achievements was carried out according to the following criteria - depth of knowledge, awareness of knowledge, system of knowledge, effectiveness of knowledge - with identification and taking into account the level of assimilation (low, moderate, medium, and high.). The test assignments of each of the "control points" consisted of 100 points; the time allocated to complete the set tasks was the same for all test participants, the criteria for evaluating the results were also the same. All works of the student that gave 0 to 40 correct answers (enrolled answers) when completing the test assignments were considered to be a low level of academic performance. The moderate level of academic performance includes all works of the students that gave 41 to 74 correct answers. The quantitative indicator for the medium level of academic performance is 75-89 points (correct answers), for the high level - 90-100 points (this scale of evaluation of student's academic performance was based on the scale of evaluation of academic performance of students by ECTS, which is currently used in higher educational institutions of Ukraine).

At the summative stage, a sample of the study was formed, the summative measurement was performed and the data obtained were analysed. The next was conducting a formative assessment, collecting and processing the data obtained. The final stage was aimed at interpreting the statistics, comparing the results with those expected, developing recommendations and prospects for further research.

\subsection{Formation of Research Sample}

This study involved 372 students of the first and third years of study of Speciality 081: Law and 14 lecturers of higher educational institutions (Khmelnytskyi University of Management and Law, Chernihiv State Institute of Law, Social Technologies and Labour, Chernihiv National University of Law, Social Technology and Labour, Chernihiv National University of Technology, State University of Infrastructure and Technology (Kyiv), Kherson branch of the Odesa State University of Internal Affairs, Academy of Labour, Social Relations and Tourism (Kyiv)). An online sample validation calculator was used to determine the representative sample. With the input figures of $\mathrm{n}=386$, $\mathrm{MOE}=10 \%$, the confidence level of $95 \%$, the response distribution of 50\%. The experimental (EG) and control (CG) groups were formed taking into account the specified number. The experimental group (EG) consisted of 28 people; the control group (CG) consisted of 29 people. The comparative analysis was carried out within the existing academic groups, where professional training was carried out according to typical programmes. In the control group, professional and linguistic training were carried out according to typical methods, and in the experimental group according to the experimental method, with the use of cloud technologies (Moodle platform, Google Drive, Google Docs, Power Point and Google Image, Google Search and Skype) in the process of formation of critical thinking in future lawyers. The same tests were used to evaluate students' academic performance in both groups at the same time (at each of the seven "control points"). The conditions and criteria for evaluating the results were also applied in the same way.

\subsection{Tools for Collecting and Processing Statistics}

The method of test control and the method of component analysis were used to diagnose the level of academic performance of students selected for the pedagogical experiment in the training courses (Chernilevsky, 2010). To accomplish the research objectives, the results of the author's tests (seven control points) performed by students of both groups. IBM SPSS Statistics 25.0.0.1 software was used to analyse the quantitative data. Two-tailed P-value and Student's $t$ test were calculated for statistical processing of experimental data. 


\section{Results}

At the summative stage, the students of the control and experimental groups were diagnosed according to the testing determined in the methodological framework of the study as the "control point No. 1". The data obtained during the summative assessment are presented in Table 1.

Table 1. Academic performance of students of the experimental and control groups

\begin{tabular}{|c|c|c|c|c|c|c|c|}
\hline \multirow[b]{2}{*}{ Academic Course } & \multirow[b]{2}{*}{$\begin{array}{c}\text { Group } \\
\text { (number } \\
\text { of people) }\end{array}$} & \multicolumn{4}{|c|}{ Levels of academic performance } & \multirow{2}{*}{$\begin{array}{l}\text { Weighted } \\
\text { average of } \\
\text { academic } \\
\text { performance } \\
\text { in a group }\end{array}$} & \multirow[b]{2}{*}{$\begin{array}{c}\text { Two-tailec } \\
\text { P-value }\end{array}$} \\
\hline & & 3 & 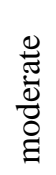 & $\begin{array}{l}\Xi \\
: \\
\Xi \\
\Xi\end{array}$ &.$\frac{500}{2}$ & & \\
\hline \multirow{2}{*}{ Civil Law } & $\begin{array}{l}\text { EG (28 } \\
\text { people) }\end{array}$ & 14 & 11 & 1 & 2 & 0.4195 & \multirow{2}{*}{0.6453} \\
\hline & $\begin{array}{l}\text { CG }(29 \\
\text { people })\end{array}$ & 12 & 12 & 4 & 1 & 0.448 & \\
\hline \multirow{2}{*}{$\begin{array}{c}\text { Fundamentals of } \\
\text { Administrative Law }\end{array}$} & $\begin{array}{l}\text { EG }(28 \\
\text { people })\end{array}$ & 18 & 6 & 3 & 1 & 0.384 & \multirow{2}{*}{0.5689} \\
\hline & $\begin{array}{l}\text { CG }(29 \\
\text { people })\end{array}$ & 14 & 10 & 5 & --- & 0.42225 & \\
\hline \multirow{2}{*}{$\begin{array}{c}\text { English for Specific } \\
\text { Purposes }\end{array}$} & $\begin{array}{l}\text { EG }(28 \\
\text { people })\end{array}$ & 16 & 6 & 2 & 4 & 0.44625 & \multirow{2}{*}{0.7903} \\
\hline & $\begin{array}{l}\text { CG }(29 \\
\text { people })\end{array}$ & 15 & 8 & 3 & 3 & 0.44775 & \\
\hline \multirow{2}{*}{ Business English } & $\begin{array}{l}\text { EG ( } 28 \\
\text { people) }\end{array}$ & 8 & 10 & 6 & 4 & 0.5535 & \multirow{2}{*}{0.4457} \\
\hline & $\begin{array}{l}\text { CG (29 } \\
\text { people) }\end{array}$ & 11 & 10 & 4 & 4 & 0.50875 & \\
\hline
\end{tabular}

In order to be able to compare the figures of the experimental and control groups in the training courses selected for the experiment before conducting the pedagogical experiment, we determined the weighted average of the academic performance of each training course for both groups involved in the experiment by IBM SPSS Statistics 25.0.0.1. software. In the Civil Law training course, control group indicators outperform those of the experimental group by 0.0285. Similarly, for the training courses Fundamentals of Administrative Law and English for Specific Purposes, the weighted average of the academic performance of the control group is higher than that of the experimental group by 0.03825 and 0.0015 , respectively. For the Business English course, the experimental group's values slightly outperformed the control group's (by 0.04475). Because the weighted average of the academic achievement has differences, we additionally calculated a two-sided P-value for each training course (see Table 1, last column). For this purpose, an online resource was used to calculate the independent sequences t-test (Graphpad, n.d.). For the results of testing at control point No. 1 for each training course, we came to the same conclusion that, by conventional criteria, the difference between the experimental and control groups was considered statistically insignificant. Therefore, it was concluded that, at the summative stage of the study, the characteristics of the experimental and control group, although they differ, are quite comparable.

As provided by the research design, the academic performance of students of the experimental and control groups for Civil Law, Fundamentals of Administrative Law, English for Specific Purposes and Business English during the academic year were measured using tests at the said control points. The results of measurements at control point No. 7 (after conducting a pedagogical experiment) are given in Table 2. 
Table 2. Academic performance of students of experimental and control groups (control point No. 7)

\begin{tabular}{|c|c|c|c|c|c|c|c|}
\hline \multirow[b]{2}{*}{ Academic Course } & \multirow[b]{2}{*}{$\begin{array}{c}\text { Group } \\
\text { (number } \\
\text { of people) }\end{array}$} & \multicolumn{4}{|c|}{ Levels of academic performance } & \multirow[b]{2}{*}{$\begin{array}{l}\text { Weighted average } \\
\text { of academic } \\
\text { performance in a } \\
\text { group }\end{array}$} & \multirow[b]{2}{*}{$\begin{array}{c}\text { Two-tailed } \\
\text { P-value }\end{array}$} \\
\hline & & 3 & 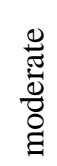 & $\underset{\Xi}{\Xi}$ & $\frac{.60}{20}$ & & \\
\hline \multirow{2}{*}{ Civil Law } & $\begin{array}{l}\text { EG }(28 \\
\text { people })\end{array}$ & 2 & 10 & 9 & 7 & 0.5935 & \multirow{2}{*}{0.0234} \\
\hline & $\begin{array}{l}\text { CG }(29 \\
\text { people })\end{array}$ & 8 & 14 & 5 & 2 & 0.5186 & \\
\hline \multirow{2}{*}{$\begin{array}{c}\text { Fundamentals of } \\
\text { Administrative Law }\end{array}$} & $\begin{array}{l}\text { EG }(28 \\
\text { people })\end{array}$ & 4 & 11 & 9 & 4 & 0.48495 & \multirow{2}{*}{0.0392} \\
\hline & $\begin{array}{l}\text { CG }(29 \\
\text { people })\end{array}$ & 9 & 12 & 7 & 1 & 0.46927 & \\
\hline \multirow{2}{*}{$\begin{array}{c}\text { English for Specific } \\
\text { Purposes }\end{array}$} & $\begin{array}{l}\mathrm{EG}(28 \\
\text { people })\end{array}$ & 2 & 5 & 11 & 10 & 0.57164 & \multirow{2}{*}{0.0245} \\
\hline & $\begin{array}{l}\text { CG }(29 \\
\text { people })\end{array}$ & 3 & 12 & 9 & 5 & 0.50131 & \\
\hline \multirow{2}{*}{ Business English } & $\begin{array}{l}\text { EG }(28 \\
\text { people })\end{array}$ & 1 & 6 & 12 & 9 & 0.6779 & \multirow{2}{*}{0.0149} \\
\hline & $\begin{array}{l}\text { CG }(29 \\
\text { people })\end{array}$ & 5 & 10 & 8 & 6 & 0,58925 & \\
\hline
\end{tabular}

Comparing the test results to the experiment (control point No. 1) and at the end of the experiment (control point No. 7), some changes are evident even without applying additional tools. In all educational courses at control point No. 1, the largest number of students showed a low level of academic performance, the second largest proportion of students of both experimental and control groups showed a moderate level of academic performance. Students with medium level of academic performance accounted for 4 to 20 percent of the total number of students in their group. A high level of academic performance was demonstrated by individual students (up to 10 percent of students in law courses and 10 to 14 percent of students in linguistic subjects).

Analyzing the conducted research, the experimental and the control group had positive shifts in the assimilation of the content of the training courses and in the formation and development of critical thinking during the experiment. The data in the column Weighted average of academic performance in a group are indicative in comparison with the results obtained at control point No. 1. For the Civil Law course, the "increase" of the indicator during the pedagogical experiment in the experimental group was +0.174 , and +0.0706 in the control group. For the Fundamentals of Administrative Law course, the increase in the indicator during the pedagogical experiment in the experimental group was +0.10095 , while in the control group it was +0.04702 . For the English for Specific Purposes course, the experimental group achieved an increase in the weighted average of academic performance of +0.12539 , and the control group "increased" its indicators by +0.05354 . For the Business English course, the weighted average in the experimental and control groups also increased by +0.1244 and +0.0805 , respectively.

In general, the formative assessment revealed positive changes in both the experimental and control groups. Therefore, in order to confirm or refute the hypothesis of the study, additional analysis was conducted using the methods of statistical processing of experimental data. Using the online calculator, we calculated the two-sided P-value to compare the results of the experimental and control groups obtained after conducting the pedagogical experiment at control point No. 7 (the obtained values of this statistical indicator are shown in the last column of Table 2). The output of the software for the calculated results for each training course: by conventional criteria, the difference between the experimental and control groups is considered statistically significant $\left(d_{f}=55\right.$; confidence interval $=95 \%$ ).

In addition, we analysed the data obtained during the pedagogical experiment using Student's t-test. Nominal categorical variable, significant I cannot be ordered. 
The Chinese operating system, which is still in full scale, is experiencing a turning point, a wider range of frequencies and significance in the array. For two independent samples of a total of 57 individuals (NEG $=28$, NCG $=29$; degree of freedom is 55), $t_{\text {tabl }}=2.004$. The Student's t-test values calculated by the software for the result obtained for the Civil Law course $t_{\text {experim }}=2.3324$, for the Fundamentals of Administrative Law course equals $t_{\text {experim. }}=2.1126$, for the English for Specific Purposes equals $t_{\text {experim }}=2.3121$, for the Business English course equals $t_{\text {experim }}=2.5128$. As each of the indicators of $t_{\text {experim. }}$ obtained (for the Civil Law, Fundamentals of Administrative Law, English for Specific Purposes and Business English courses) exceeds $t_{\text {tabl. }}=2.004$, the hypothetical assumption that the use of cloud technologies in the process of professional and linguistic training will contribute to the formation and development of critical thinking in future lawyers was confirmed experimentally.

To analyse the dynamics of changes in the academic performance of students in the experimental and control groups, we calculated the weighted average values of academic performance for each training course at each of the seven control points using IBM SPSS Statistics 25.0.0.1. The obtained weighted average values of academic performance at control points 1-7 gave an opportunity to graphically demonstrate the dynamics of changes in students of the experimental and control groups during the pedagogical experiment. The dynamics of changes in academic performance of students in the Civil Law course is shown in Figures 1, 2 presents the data obtained during the experiment for the Fundamentals of Administrative Law course. Figure 3 illustrates the dynamics of changes in the weighted average values of students' academic performance for the English for Specific Purposes course. Figure 4 contains a visualization of experimental data for the Business English course.

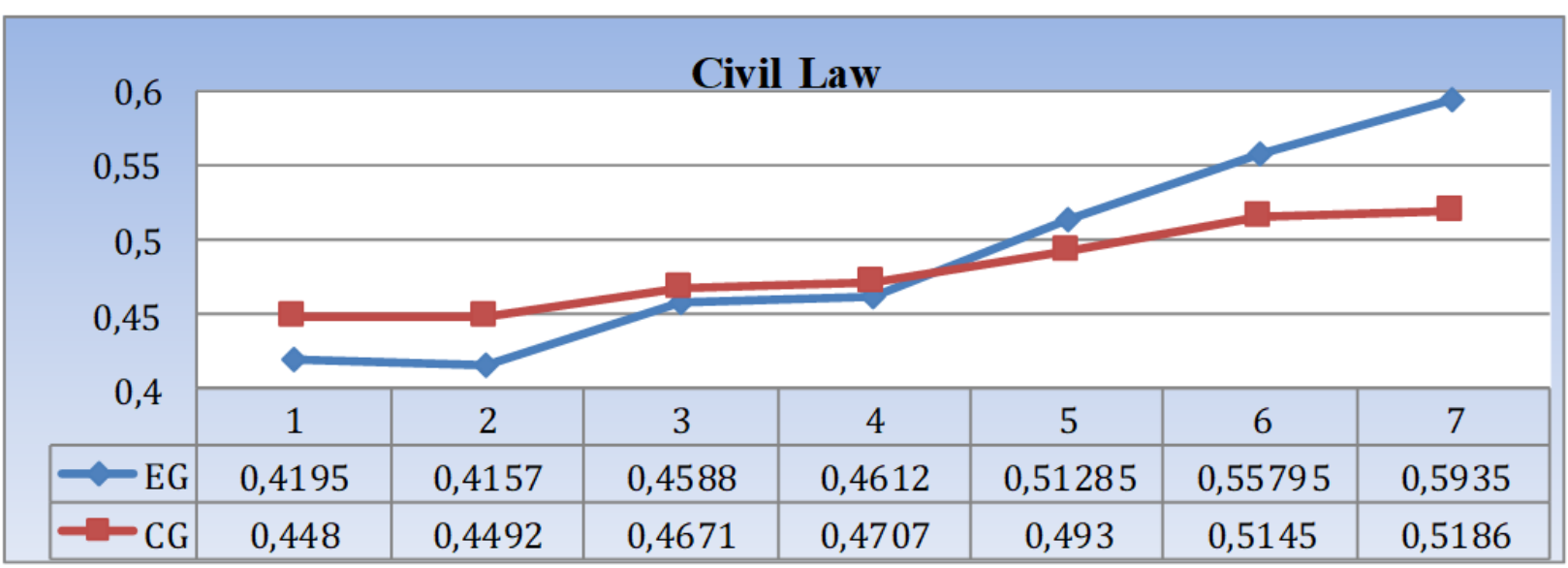

Figure 1. Dynamics of changes in the weighted average values of the academic performance of students of experimental and control groups (control points 1-7)

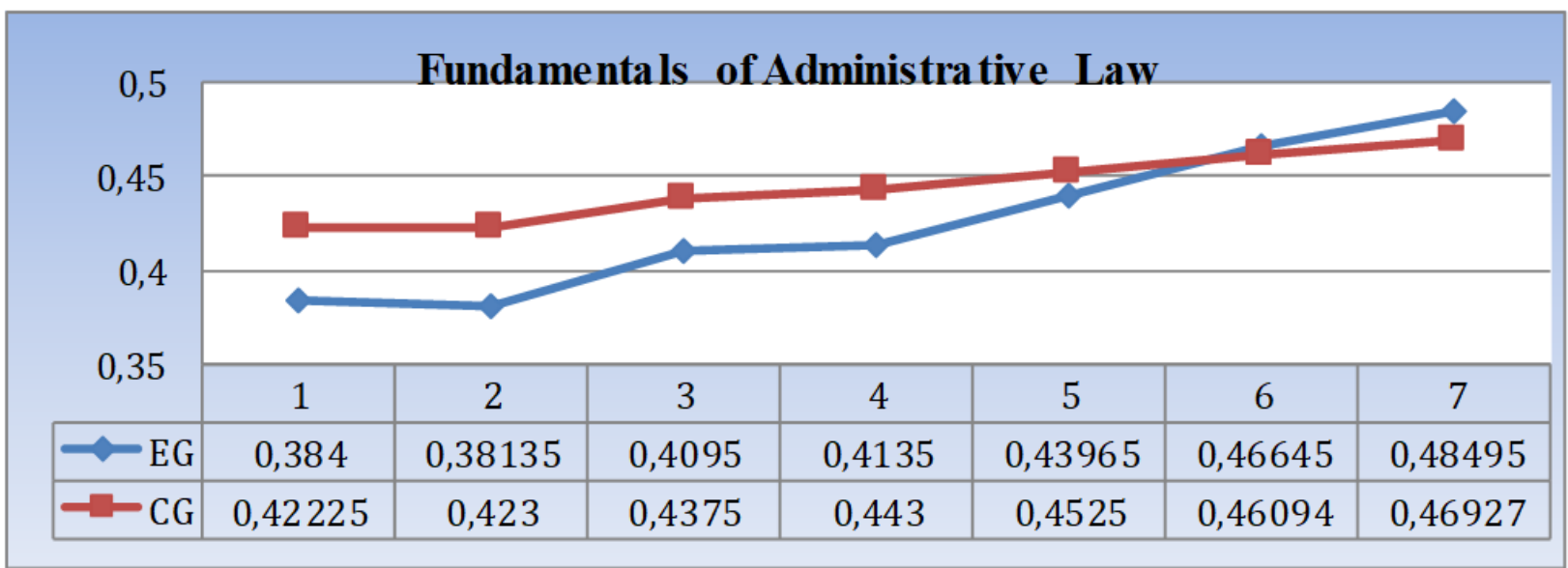

Figure 2. Dynamics of changes in the weighted average values of the academic performance of students of experimental and control groups (control points 1-7) 


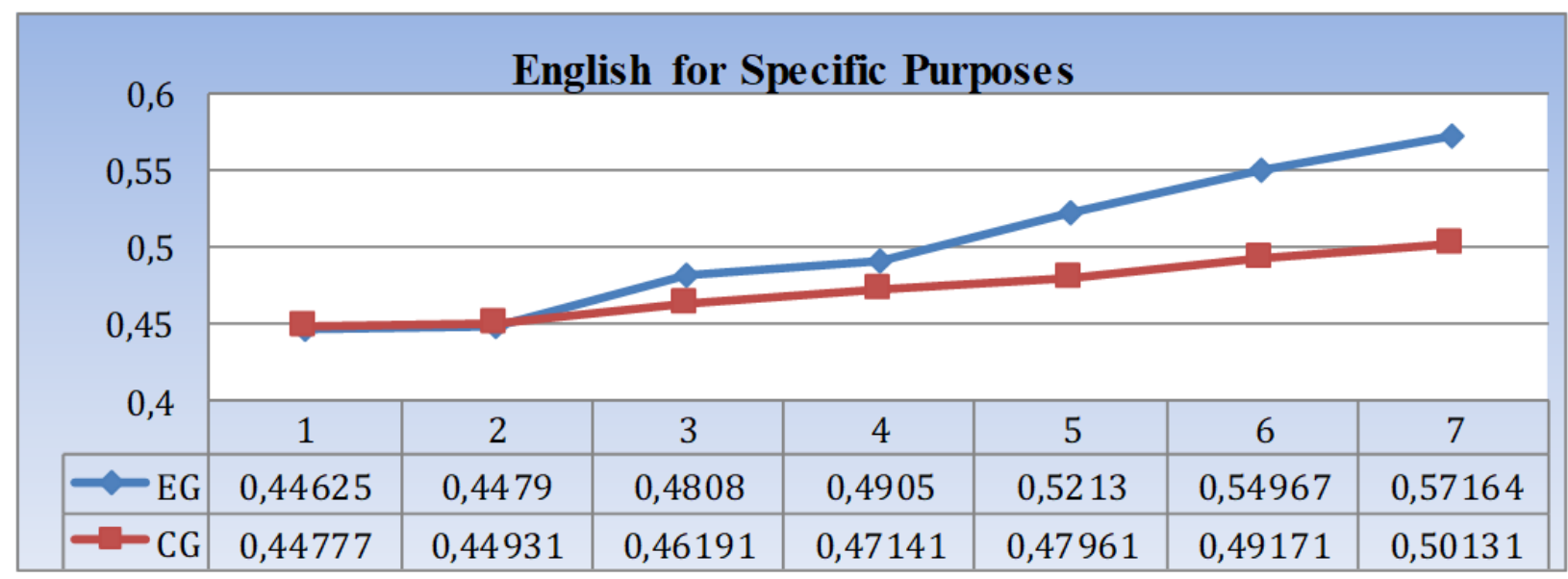

Figure 3. Dynamics of changes in the weighted average values of the academic performance of students of experimental and control groups (control points 1-7)

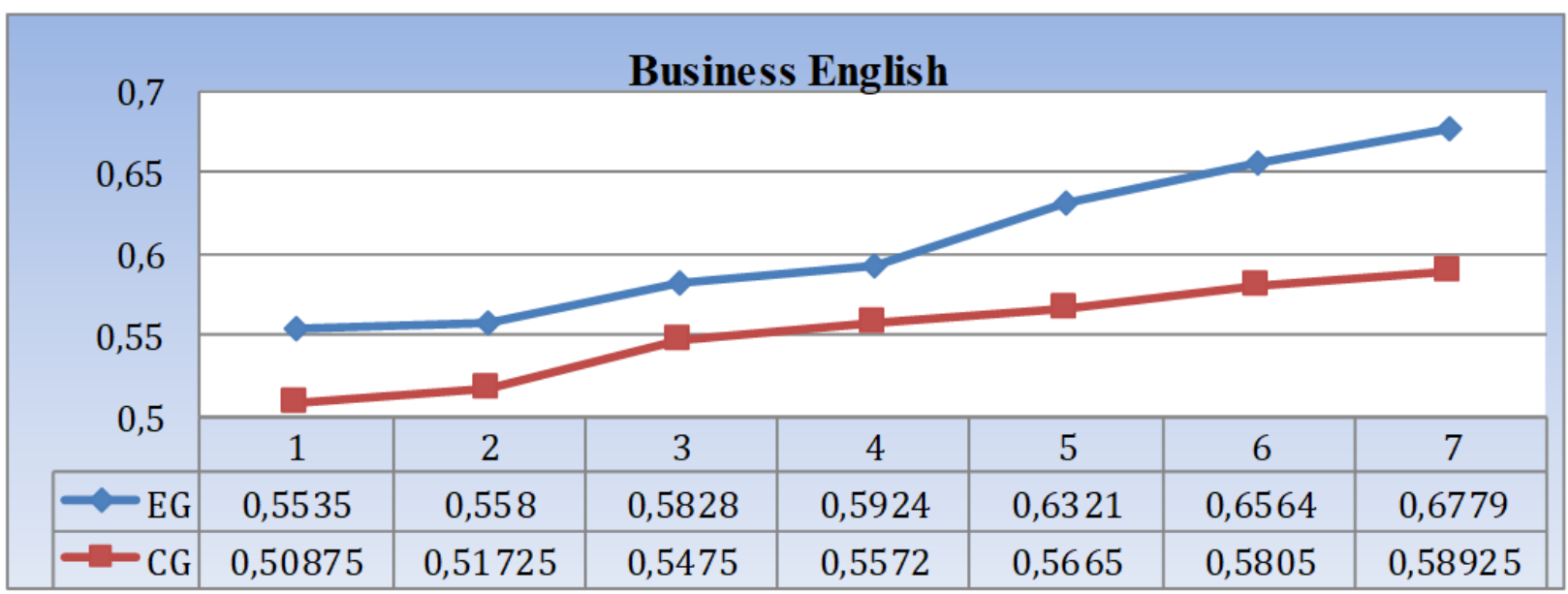

Figure 4. Dynamics of changes in the weighted average values of the academic performance of students of experimental and control groups (control points 1-7)

All four figures clearly show some interesting, in our opinion, moments. First, prior to conducting a pedagogical experiment, the "starting position" of the experimental group in relation to the control group may be different (slightly lower for the Civil Law and Fundamentals of Administrative Law courses, almost the same for the English for Specific Purposes course, slightly higher for the Business English course); however, after the completion of the pedagogical experiment, the "position" of the experimental group outweighs the "position" of the control group. Second, in general, the lines that reflect the dynamics of change in the academic performance of students of the control group in the selected training courses are smoother compared to the lines relating to the experimental group.

The third interesting feature is demonstrated by control point No. 2 (this is noticeable both in the chart and in the tabular data). In the experimental group, the weighted average values of students' academic performance for the Civil Law (Figure 1) and the Fundamentals of Administrative Law (Figure 2) courses are even lower than at control point No. 1. Experimental group indicators at control point No. 2 for the English for Specific Purposes (Figure 3) and Business English training courses (Figure 4) either remain virtually unchanged or increase insignificantly. At the same time, in the control group, the weighted average values of students' academic performance increase insignificantly across all training courses. Interviews conducted with the students and teachers involved in the experiment allowed explaining the found peculiarity by the fact that control point No. 2 was the time when the students of the experimental group experienced objective difficulties during the period of transition and adaptation to the new organizational conditions for delivering lectures/practical classes. In addition, for both the experimental and 
the control groups, the tests of control point No. 2 were unusual and contained modified assignments (open-ended, multiple-choice, etc.) that required students to apply different elements and types of critical thinking (reflective, subject, operational, communicative).

The next point in our review will be the line gap between control points No. 3 and No. 4. The increase in the weighted average values of students' academic performance in both groups for all four courses slows down significantly, recovering at different speeds after control point No. 4. Figures of control point No. 4 turned out to be lower than we expected. The fact is that control point No. 4 falls on the exam session. According to the students, at that time they were "pressured" by other training courses, the need to allocate time to the urgent completion of the assignments and work not submitted in due time.

In view of the above, the line gap between control points No. 6 and No. 7 is even more interesting for analysis. This period also falls on the time the students prepare for the examination period. However, the pattern of changes in the weighted average values of students' academic performance differs. In the control group, the dynamics of indicators slowed down again, as well as on the gap between control points No. 3 and No. 4, that is, students feel the "pressure" of the examination period again. At the same time, we do not observe such slowdown in the experimental group. From the interviews with the students of the experimental group during this period, we conclude that they have already adapted to the "new" organizational conditions for delivering lectures/practical classes and created their own models of rational organization of their time. We believe that this has reduced the pressure of the examination period.

The analysis of interviews with students of the experimental group and teachers involved in the pedagogical experiment also reveals marked changes in the motivational and personality spheres of student development.

\section{Discussion}

It is often stated that students learn to more rationally allocate their time, create their own ways of finding information and presenting it, learn to more clearly and significantly reason their decision and defend their point of view, etc. No special study and analysis of these changes was, however, performed as this study did not provide for that.

There is no need to prove that the introduction of new organizational conditions in the process of professional and linguistic training of future specialists, skilful pedagogical management of the process of formation and development of critical thinking in students, monitoring and increasing students' motivation for learning and constant changes in their personality sphere require active interaction between teachers and students. Under these conditions, the organization of the educational process changes the roles of both teacher and student. The teacher is tasked with finding the most appropriate means of transferring the actual content core of the subject using modern innovative teaching technologies, not only changing (developing or modifying) teaching materials and means of control, but also creating special atmosphere for evoking students' interest in their own development. Modern higher education pedagogy believes that it is the teacher who should influence the formation of students' reflective abilities, ensure the active role of students in learning, as well as their awareness of their social role. Modern educator should be competent, technologically aware, flexible, convincing in the reasonability of applying new approaches in teaching. Under such requirements, the teacher faces with the need for painful changes in himself/herself, in his/her established system of presentation and monitoring of educational content even before the purposeful work on "reformatting" student stereotypes in teaching begins. Our research convincingly demonstrates that the collaboration of all actors in the educational process is necessary for innovative ways of learning to become traditional generally used.

For the formation and development of skills and effective styles of critical thinking in future specialists, researchers suggest to purposefully organize practice-oriented learning activities of students (Evdokimov, Oleinik, Gorkova \& Mikityuk, 2002; Heijltjes, van Gog \& Paas, 2014), training students in completing complex assignments based on decision-making algorithms and models (Helsdingen, van den Bosch, van Gog \& van Merriënboer, 2010). But the most promising is the use of modern information and communication technologies (Dendev, 2013; Scherer, Siddiq \& Sánchez Viveros, 2019), which is quite understandable in the context of growth of informatization of society and rapid growth of information technologies. The so-called "cloud" technologies attracted our attention among many modern information technologies; they are considered as innovative (Masud \& Huang, 2012) and having huge potential in the educational field (Stevenson \& Hedberg, 2011). Researchers emphasize the existence of a number of benefits of cloud technologies in their application for educational purposes, namely the ability to access educational materials and information resources anywhere anytime (Shi, Yang, Yang \& Wu, 2014), fundamentally new ways of organizing research and/or project activity (Odeh et al., 2017), cost savings for software acquisition, no need for specialized premises, no advertising content, anti-virus and anti-hacker security, openness to the educational 
environment for teachers and students (Demir-Yildiz \& Tatik, 2019; Pozdnyakov, 2012), the ability to perform many types of educational work, control and evaluation online (online lessons, webinars, integrated practical classes, "cooperative" laboratory work, trainings, round tables, etc.) (Blue \& Tirotta, 2011).

\section{Conclusions}

The introduction of innovative technologies into the educational process and the formation of critical thinking in students is the most optimal way to resolve the contradictions between the needs of a modern and rapidly changing society and the current practice of professional training, especially in law.

The conducted research shows that the reorganization of the educational process in the higher educational institution towards using cloud technologies and the corresponding methods of delivering lectures and practical classes, methods of evaluating the learning outcomes is a factor for more effective formation and development of critical thinking in students. The proposed model has been tested in the training courses of academic subjects in Specialty "Law". Therefore, the use of experimental "achievements" in the practice of teaching most training courses will significantly increase the rate of formation and development of critical thinking in future lawyers. We believe that the results of the study can be extrapolated to the process of professional training of specialists in other specialties in order to form students' critical thinking and improve the quality of professional training as a whole.

The largest limiting factor in our study was the heterogeneous level of gadget use skills among students; insufficient training of teachers (availability of online manuals, ability and desire to work in Moodle) and higher educational institutions (availability of opportunities to connect to Moodle and other resources) for the use of existing cloud technologies in the educational and teaching process.

In addition, the coordination of organizational features of delivering lectures/practical classes to teachers, counselling teachers on using the "inverted lesson" method (method for monitoring and evaluation of student's academic performance, modification and unification of test assignments to measure students') and the portofolio (this is a method designed to systematize the results of independent work of students, generalization, deepening and expanding the knowledge gained in the classroom).

\section{Suggestions}

It should also be noted that the proposed approach (the use of cloud technologies) allows making only the first step to the formation of critical thinking, so it cannot provide an automatic solution to all tasks of higher education. For example, the creation of high-quality, convenient and operational means of monitoring and diagnosing changes in the cognitive, motivational and personality development of students require further research and development. It is also necessary to encourage teachers and management of higher educational institutions to broadly and continuously introduce innovative technologies into the professional training of future specialists.

\section{Limitations}

This study was planned to find out how effective the use of cloud technologies was in the formation and development of critical thinking in lawyers while their professional and linguistic training. The results of the experiment undoubtedly show that cloud technologies give the opportunity to create such a learning environment, which allows increasing significantly the quality of professional training of students through the formation and development of critical thinking and other professional skills and competencies. However, the experiment does not allow estimating how consistent young professionals will be in implementing critical thinking in approaching non-academic legal tasks; how the formation level of critical thinking in students will influence the speed of their adaptation in the workplace and the primary professional socialization. It also shows what factors could provide a stable development and widening of critical thinking as an essential characteristic of a modern specialist in the future.

\section{References}

Beyer, B. K. (1985). Critical thinking: What is it? Social Education, 49, 270-276.

Bloom, B. S., Engelhart, M. D., Furst, E. J., Hill, W. H., \& Krathwohl, D. R. (1956). Taxonomy of Educational Objectives: The Classification of Educational Goals. New York, NY: Longman.

Blue, E., \& Tirotta, R. (2011). The benefits \& drawbacks of integrating cloud computing and interactive whiteboards in teacher preparation. TechTrends, 55, 31-39. https://doi.org/10.1007/s11528-011-0495-7

Cheng, J.-S., Huang, E., \& Lin, C.-L. (2012). An e-book hub service based on a cloud platform. The International Review of Research in Open and Distributed Learning, 13(5), 39-55. https://doi.org/10.19173/irrodl.v13i5.1251 
Chernilevsky, D. V. (2010). Pedagogy of high school. $2^{\text {nd }}$ edition. Vinnytsia, Ukraine: Academy of International Collaboration in Creative Pedagogy.

Davies, A., Fidler, D., \& Gorbis, M. (2011). Future Work Skills 2020. Palo Alto, CA: Institute for the Future for the University of Phoenix Research Institute

Demir-Yildiz, C., \& Tatik, R. S. (2019). Impact of Flexible and Non-flexible Classroom Environments on Learning of Undergraduate Students. European Journal of Educational Research, 8(4), 1159-1173. https://doi.org/10.12973/eu-jer.8.4.1159

Dendev, B. (2013). Information and communication technologies in education: a monograph. Moscow, Russia: UNESCO IITE.

Dychkivska, I. M. (2013). Innovative pedagogical technologies: Workshop: Study guide for students. Kyiv, Ukraine: Slovo.

Evdokimov, V. I., Oleinik, T. A., Gorkova, S. A., \& Mikityuk, M. A. (2002). Workshop on the development of critical thinking. Kharkiv, Ukraine: Tornado.

Ghazivakili, Z., Norouzi Nia, R., Panahi, F., Karimi, M., Gholsorkhi, H., \& Ahmadi, Z. (2014). The role of critical thinking skills and learning styles of university students in their academic performance. Journal of Advances in Medical Education \& Professionalism, 2(3), 95-102.

Graphpad. (n.d.). QuickCalcs. Retrieved from https://www.graphpad.com/quickcalcs/ttest1

Harris, D. H., \& Spiker, A. V. (2012). Critical thinking skills for intelligence analysis. In I. L. Nunes (Ed.), Ergonomics - A Systems Approach, 209-232. Rijeka, Croatia: Intech. https://doi.org/10.5772/34634

Heijltjes, A., van Gog, T., \& Paas, F. (2014). Improving students' critical thinking: Empirical support for explicit instructions combined with practice. Applied Cognitive Psychology, 28(4), 518-530. https://doi.org/10.1002/acp.3025

Helsdingen, A. S., van den Bosch, K., van Gog, T., \& van Merriënboer, J. J. G. (2010). The Effects of Critical Thinking Instruction on Training Complex Decision Making. Human Factors, 52(4), 537-545. https://doi.org/10.1177/0018720810377069.

Huong, H. T. L., Huy, N. H. D., \& Ha, N. N. (2018). The Flipped Classroom: Using Thematic Teaching to Develop Critical Thinking for High School Students. American Journal of Educational Research, 6(6), 828-835. https://doi.org/10.12691/education-6-6-36

Isaienko, S., \& Kushmar, L. (2016). Professional culture formation in students: negative factors to be eliminated. Humanitarny Visnyk Pereyaslav-Hmelnytskogo Derzhavnogo Pedagogichnogo Universytetu imeni Hryhoriya Skovorody, 36, 102-111.

Kaya, S. (2019). A comparison between the fifth grade intensive English language curriculum and the fifth grade English language curriculum: Students' achievement in speaking. European Journal of Educational Research, 8(4), 921-933. https://doi.org/10.12973/eu-jer.8.4.921

Korsunska, L. M. (2013). Korean smart education concept: general education, digital smart-school textbooks. Education and Development of Gifted Personality, 11, 77-80.

Masud, M. A. H., \& Huang, X. (2012). A novel approach for adopting cloud-based e-learning system. In J. E. Guerrero (Ed.), Proceedings of the 2012 IEEE/ACIS 11th International Conference on Computer and Information Science in Shanghai, China, 37-42. Piscataway, NJ: The Institute of Electrical and Electronics Engineers, Inc. https://doi.org/10.1109/ICIS.2012.10

Minchekar, V. S. (2017). The Role of cognitive style in creative thinking among college students. Psychology and Behavioral Science International Journal, 6(1), 555-679. https://doi.org/10.19080/PBSIJ.2017.06.555679

Ministry of Education and Science of Ukraine. (2016). Resolution No. 3/1-19 On the state of implementation of the "Cloud services in education" project to increase digital literacy of teachers in the framework of non-formal education for days. Retrieved from https://mon.gov.ua/ua/npa/pro-stan-zaprovadzhennya-proektu-khmarni-servisi-v-osviti-z-metoyu-pidvishchenny a-tsifrovoi-gramotnosti-vchiteliv-v-ramkakh-neformalnoi-osviti-dlya-doroslikh

Ministry of Education and Science of Ukraine. (2017). Order \#1582 on ceasing the experimental research work on the topic "Cloud services in education". Retrieved from 
https://mon.gov.ua/ua/npa/pro-zavershennya-doslidno-eksperimentalnoyi-roboti-za-temoyu-hmarni-servisi-v-os viti

North, J. S., Ward, P., Ericsson, A., \& Williams, A. M. (2011). Mechanisms underlying skilled anticipation and recognition in a dynamic and temporally constrained domain. Memory, 19(2), 155-168. https://doi.org/10.1080/09658211.2010.541466

Odeh, M., Garcia-Perez, G., \& Warwick, A. (2017). Cloud computing adoption at higher education institutions in developing countries: a qualitative investigation of main enablers and barriers. International Journal of Information and Education Technology, 7(12), 921-927. https://doi.org/10.18178/ijiet.2017.7.12.996

Oliynyk, T. O. (2004). Portfolio as a tool for qualitative assessment of educational achievement. Theory and methodology of teaching and upbringing, 14, 123-129.

Pozdnyakov, V. A. (2012). Practical realization of the adaptive subsystem of ensuring quality of training of pedagogical staff on the basis of the cloud computing technology. Pedagogical Education in Russia, 6, 70-75.

Ritchie, S. J., Bates, T. C., \& Deary, I. J. (2015). Is education associated with improvements in general cognitive ability, or in specific skills? Developmental Psychology, 51(5), 573-582. https://doi.org/10.1037/a0038981

Romiszowski, A. J. (2012). Distance learning and cloud computing: Just another buzzword or a major e-learning breakthrough? Educational Technology, 52(5), 42-45.

Sadler, G. B. (2010). Reconciling Four Models of Critical Thinking: FSU QEP, Paul-Elder, CLA, and APA Delphi. Fayetteville, NC: Fayetteville State University.

Scherer, R., Siddiq, F., \& Sánchez Viveros, B. (2019). The cognitive benefits of learning computer programming: A meta-analysis of transfer effects. Journal of Educational Psychology, 111(5), 764-792. https://doi.org/10.1037/edu0000314

Serin, O., Serin, N. B., Saracaloglu, A. S., \& Ceylan, A. (2010). The examination of critical thinking styles of university students (TRNC Sample). Social and Behavioral Sciences, 9, 864-868. https://doi.org/10.1016/j.sbspro.2010.12.250

Sharma, P., \& Neetu. (2011). A study of learning-thinking style of secondary school students in relation to their academic achievement. International Journal on New Trends in Education and Their Implications, 2(4), $115-123$.

Shi, Y., Yang, H. H., Yang, Z., \& Wu, D. (2014). Trends of cloud computing in education. In S. K. S. Cheung, J. Fong, J. Zhang, R. Kwan, \& L. F. Kwok (Eds.), Hybrid Learning. Theory and Practice, 116-128. Cham, Switzerland: Springer. https://doi.org/10.1007/978-3-319-08961-4_12

Siegle, D. (2010). Cloud computing: A free technology option to promote collaborative learning. Gifted Child Today, 33(4), 41-45. https://doi.org/10.1177/107621751003300410

Smith, M. D. (2017). Cognitive validity: Can multiple-choice items tap historical thinking processes? American Educational Research Journal, 54(6), 1256-1287. https://doi.org/10.3102/0002831217717949

Solomko, M. T. (2013). The use of electronic technology education in the training of students of pedagogical skills. Updating the content, forms and methods of education and training in educational institutions, 7(50), $187-194$.

Stevenson, M., \& Hedberg, J. G. (2011). Head in the clouds: A review of current and future potential for cloud-enabled pedagogies. Educational Media International, 48(4), 321-333. https://doi.org/10.1080/09523987.2011.632279

Temple, C. (2005). Critical thinking and critical literacy. Change, 2, 15-20.

Willingham, D. T. (2019). How to Teach Critical Thinking. Sydney, Australia: New South Wales Department of Education.

Ziętek, A. A., \& Roehr, K. (2011). Metalinguistic knowledge and cognitive style in Polish classroom learners of English. System, 39(4), 417-426. https://doi.org/10.1016/j.system.2011.05.005 